\title{
Distribution of Eppin in mouse and human testis
}

\author{
YAN LONG, AIHUA GU, HUA YANG, GUIXIANG JI, XIUMEI HAN, \\ LING SONG, SHOULIN WANG and XINRU WANG
}

Key Laboratory of Reproductive Medicine, Institute of Toxicology, Nanjing Medical University, Nanjing 210029, P.R. China

Received August 31, 2010; Accepted November 29, 2010

DOI: $10.3892 / \mathrm{mmr} .2010 .403$

\begin{abstract}
The human Eppin (hEppin) (SPINLW1; Epididymal protease inhibitor) gene was first described and sequenced in 2001, and later identified as an immunocontraceptive target for males in 2004. The expression and function of the mouse eppin (mEppin) gene was first described in 2003, and recent studies have shown that mEppin protein has a similar male contraceptive effect in mice. In this study, we designed a probe to detect mEppin mRNA in frozen sections from the testes of 60-day-old mice as well as in the GC-1, GC-2 and MLTC-1 cell lines, using a hyperbiotinylated oligonucleotide DNA probe. In addition to Sertoli cells, the expression of mEppin mRNA was localized to the spermatogonia, spermatocytes and Leydig cells. Subsequent RT-PCR and Western blot analysis confirmed the results of the in situ hybridization. Immunohistochemistry was performed on corresponding sections of mouse and human testis using an anti-c-kit antibody to detect spermatogonia and an anti-eppin antibody to detect Eppin protein. The expression of mEppin protein was detected in A1-A4 spermatogonia and the expression of hEppin was detected in type A spermatogonia as well as in the earliest preleptotene spermatocytes. The present study demonstrates that the expression of hEppin is similar to that of mEppin, and is localized to differentiated spermatogonia. Moreover, the findings support the hypothesis that mEppin protein is secreted from Sertoli cells and taken up by spermatogonia.
\end{abstract}

\section{Introduction}

The mammalian epididymis provides a specialized microenvironment in which immature spermatozoa acquire forward motility and the capacity to fertilize ova $(1,2)$. The presence of proteases in the epididymis requires the presence of their inhibitors as an important mechanism for the regulation of regional maturation and processing of spermatozoa.

Correspondence to: Dr Xinru Wang, Key Laboratory of Reproductive Medicine, Institute of Toxicology, Nanjing Medical University, Nanjing 210029, P.R. China

E-mail: xrwang@njmu.edu.cn

Key words: eppin, spermatogonia, in situ hybridization
Previous studies have shown that a number of the key processes regulating the activity and fate of many proteins involved in epididymis are strictly dependent on proteolytic events. Therefore, proteases and protease inhibitors, which are implicated in tight junction/adherent junction (TJ/AJ) assembly (3), are important regulators of Sertoli cell TJ dynamics (4).

Human eppin (hEppin) is a member of a highly conserved family of protease inhibitors that are expressed in the testis and epididymis, and was first identified and sequenced as a novel serine protease inhibitor in 2001. The gene is located on human chromosome 20 and is characterized by three mRNAs encoding two isoforms of a cysteine-rich protein that contains both WAP-type and Kunitz-type consensus sequences $(5,6)$. The gene encodes three splice variants of Eppin: Eppin-1, -2 and -3 (5). In 2004, O'Rand et al reported the successful contraception of male non-human primates immunized with recombinant hEppin protein, and proposed that hEppin might serve as a target for male immunocontraception (7). In 2007, Wang et al found that hEppin is localized primarily to the Sertoli cells, while weak expression of hEppin was detected in myoid cells as well as spermatogenic cells (8). In order to establish an animal model to facilitate further hEppin studies, Sivashanmugam et al found that the expression of mEppin protein was localized to Sertoli, Leydig and round spermatids cells (9). It is well known that the movement of germ cells that traverse the epithelium likely involves the cyclic phase of Sertoli-Sertoli and Sertoli-germ cell junction de-adhesion and adhesion, which is partially regulated by proteases and protease inhibitors $(10,11)$. Previous studies have indicated that mEppin protein is secreted from Sertoli cells and plays a role in regulating the crosstalk between germ cells and Sertoli cells. However, to date this has not been sufficiently supported by direct experiment evidence.

In this study, we examined the mRNA distribution of mEppin in GC-1, GC-2 and MLTC-1 cell lines as well as adult mouse testis using in situ hybridization histochemistry. The expression of mEppin was found to be localized to differentiated spermatogonia in the adult mouse testis using double immunofluorescent staining. This directly shows that mEppin protein was secreted by Sertoli cells and taken up by adjacent spermatogonia. The similar localization pattern of hEppin in spermatogonia from human testis suggests that the mouse may be the suitable animal model for further investigation of hEppin. 


\section{Materials and methods}

Animals and tissue preparation. Human adult testis and testicular sections for use in the immunohistochemistry experiments were obtained from deceased individuals with informed consent according to the guidelines of the Ethical Committee of Nanjing Medical University, China. Adult male 60-day-old ICR mice weighing 20-22 g were used in the study. Frozen sections were obtained from three of the mice, and RNA and protein samples were obtained from another 3 mice. Tissue preparation was performed as previously described (12). Briefly, for in situ hybridization the mice were placed under deep anesthesia with sodium pentobarbital $(40 \mathrm{mg} / \mathrm{kg}$ body weight) and covered with ice. The animals were then transcardially perfused with $\sim 200 \mathrm{ml}$ of DEPC-treated $10 \mathrm{mM}$ PBS, followed by $300 \mathrm{ml}$ of $4 \%$ paraformaldehyde (PFA) in $0.1 \mathrm{M}$ phosphate buffer. After being kept on ice for $30 \mathrm{~min}$, the animals were perfused with 11 of $15 \%$ sucrose containing $0.1 \%$ (v/v) DEPC. The testis and epididymis were dissected and removed, wrapped with OCT embedding medium, frozen, serially cut at $-20^{\circ} \mathrm{C}$, and placed on RNase-free silane-coated glass microscope slides. The slides were stored at $-80^{\circ} \mathrm{C}$ until use. For immunohistochemistry, the human testis was excised and fixed in $4 \%$ PFA in $0.1 \mathrm{M}$ phosphate buffer for $24 \mathrm{~h}$ at $4^{\circ} \mathrm{C}$.

Cell culture. GC-1 spg (ATCC \# CRL-2053) and GC-2 spd(ts) (ATCC \# CRL-2196) cells were cultured in Dulbecco's modified Eagle's medium (DMEM) (Gibco, USA) and MLTC-1 (ATCC \# CRL-2065) were cultured in Roswell Park Memorial Institute 1640 medium (Gibco), supplemented with $10 \%$ fetal bovine serum (Hyclone, Canada), $100 \mathrm{U} / \mathrm{ml}$ penicillin and $10 \mu \mathrm{g} / \mathrm{ml}$ streptomycin (Gibco).

PCR analysis. Total RNA was isolated from GC-1, GC-2 and MLTC-1 cell lines, as well as from mouse testis and mouse liver samples using the RNeasy Mini kit (Qiagen, Japan), according to the manufacturer's instructions. The total RNA was incubated for $1 \mathrm{~h}$ with $10 \mathrm{U}$ RNase-free DNase (Roche Applied Science, Germany) and $20 \mathrm{U}$ recombinant RNase inhibitor (Takara, Japan) at $37^{\circ} \mathrm{C}$ to eliminate DNA contamination. Each RNA sample was reverse transcribed using the PrimeScript RT reagent kit (Takara) according to the manufacturer's instructions. The reverse transcription reaction conditions were as follows: $37^{\circ} \mathrm{C}$ for $15 \mathrm{~min}$ followed by $85^{\circ} \mathrm{C}$ for $15 \mathrm{sec}$. The mEppin mRNA was amplified using the following set of primers designed to amplify the entire coding region: sense primer, ATGAAGCTTTCTGGATTTGA; antisense primer, TCAGGTGAGACTGCTTTTTTT.

Amplification was performed using Premix Taq Version 2.0 (Takara) in a final volume of $50 \mu \mathrm{l}$ containing $25 \mu \mathrm{l}$ Premix Taq, $5 \mu \mathrm{l}$ DNA, $1 \mu \mathrm{l}$ sense primer, $1 \mu \mathrm{l}$ anti-sense primer and $18 \mu \mathrm{l}$ sterilized distilled water. Cycles were initiated at $95^{\circ} \mathrm{C}$ for $5 \mathrm{~min}$, followed by 35 cycles at $95^{\circ} \mathrm{C}$ for $40 \mathrm{sec}, 58^{\circ} \mathrm{C}$ for $30 \mathrm{sec}$ and $72^{\circ} \mathrm{C}$ for $40 \mathrm{sec}$, with final extension at $72^{\circ} \mathrm{C}$ for $10 \mathrm{~min}$. Each PCR product was electrophoresed at $100 \mathrm{~V}$ for 30 min and analyzed using a gel imaging appratus.

In situ hybridization. In situ hybridization was performed using the reagents and procedures described in the instructions of the In Situ Hybridization detection kit (Boster, China).
Briefly, frozen sections were fixed with 4\% PFA/0.1 M PBS (containing 1/1,000 DEPC) for $25 \mathrm{~min}$ at room temperature (RT), then washed with PBS three times and treated with $30 \%$ $\mathrm{H}_{2} \mathrm{O}_{2}$ in 50 volumes of methanol at RT for $30 \mathrm{~min}$. The sections were then washed three times with distilled water, treated with a pepsin dilution ( $1 \mathrm{ml}$ of $3 \%$ citric acid with two drops of condensed pepsin) for $90 \mathrm{sec}$ to expose the mRNA fragments, and then washed with PBS three times. Subsequently, the sections were post-fixed with $1 \%$ PFA/0.1 M PBS (containing 1/1,000 DEPC) for $10 \mathrm{~min}$ at RT, washed with distilled water three times, and then covered with pre-hybridization solution at $42^{\circ} \mathrm{C}$ for $4 \mathrm{~h}$. The solution was then discarded and the sections were covered with the hybridization probes at $42^{\circ} \mathrm{C}$ overnight. The next day, the sections were washed with $2 \mathrm{X}$ SSC twice, with $0.5 \mathrm{X}$ SSC for $15 \mathrm{~min}$, and with $0.2 \mathrm{X}$ SSC for $15 \mathrm{~min}$ at $37^{\circ} \mathrm{C}$. The sections were then blocked with blocking reagent at $37^{\circ} \mathrm{C}$ for $30 \mathrm{~min}$, incubated with biotinylated mouse anti-digoxin reagent for $120 \mathrm{~min}$ at RT, and then washed with PBS four times. Next, the sections were incubated with SABC reagent for $30 \mathrm{~min}$ at RT, washed with PBS three times, incubated with biotinylated peroxidase for $30 \mathrm{~min}$ at RT and then washed with PBS four times. Finally, the cerium-diaminobenzidine (DAB) visualization method was performed, and the sections were co-stained with hematoxylin, dehydrated with graded ethanol, vitrificated with dimethylbenzene, sealed with resinene and subsequently visualized by microscopy.

The anti-sense probes used were as follows: 1. 5'-TGTGAA CACCAAGAGAGGGACCTTTGTACCAGGGA-3'; 2. 5'-AAC AAGATATCTGCAGCCTGCCGAAAGACTCCGGC-3'; 3 . 5'-CGTTGGTGGTTTAATAAAGAAAATAGCACGTG CCA-3'. The sense probes used were as follows: 1.5'-ACACTT GTGGTTCTCTCCCTGGAAACATGGTCCCT-3'; 2. 5'-TTG TTCTATAGACGTCGGACGGCTTTCTGAGGCCG-3'; 3 . 5'-GCAACCACCAAATTATTTCTTTTATCGTGCACGGT-3'

Fluorescent immunohistochemisty. Frozen sections of mouse testis were incubated at $37^{\circ} \mathrm{C}$ for $10 \mathrm{~min}$ and washed with PBS three times. The endogenous peroxidase activity of the sections was blocked with methanol- $\mathrm{H}_{2} \mathrm{O}_{2}$ and the sections were blocked with $2 \%$ normal rabbit serum. The sections were then incubated with an anti-c-kit antibody (Ebioscience, Japan) and an anti-eppin antibody (Santa Cruz, USA) or with PBS as the negative control at $4^{\circ} \mathrm{C}$ overnight. The next day, the sections were washed with TBS and then incubated with R-PEanti-goat antibody produced in rabbits (Beyotime, China) for $1 \mathrm{~h}$ in the dark at $37^{\circ} \mathrm{C}$. The sections were washed, blocked with normal goat serum for $30 \mathrm{~min}$ at RT and then incubated with FITC-anti-rat antibody produced in goats (Beyotime) for $1 \mathrm{~h}$ in the dark at $37^{\circ} \mathrm{C}$. Finally, the sections were washed with PBS in the dark, incubated with an anti-quencher and visualized by fluorescence microscopy (Zeiss, Germany).

Sections of human testis were de-paraffinized and endogenous peroxidase activity was blocked by incubation with methanol- $\mathrm{H}_{2} \mathrm{O}_{2}$. The sections were blocked with $2 \%$ normal rabbit serum and antigen retrieval was performed by microwaving. The sections were incubated with an anti-c-kit antibody (CD117) (Ebioscience) overnight at $4^{\circ} \mathrm{C}$. The next day, the sections were washed three times with PBS and then incubated with an anti-mouse $\operatorname{IgG}$ (Fab specific)-FITC antibody (Sigma, USA) in the dark for $1 \mathrm{~h}$ at RT. Simultaneously, 
an anti-eppin antibody (Santa Cruz) was labeled with Alexa Fluor 594 using the Zenon Rabbit IgG labeling kit (Molecular Probes, USA) according to the manufacturer's instructions. Briefly, $1 \mu \mathrm{g}$ of antibody was diluted in PBS to a maximal volume of 20 , and $5 \mu \mathrm{l}$ of the labeling reagent was added to the antibody solution. The reaction mixture was then incubated in the dark for $5 \mathrm{~min}$ at RT. Finally, $5 \mu \mathrm{l}$ of the blocking reagent was added to the reaction mixture and incubated in the dark for $5 \mathrm{~min}$ at RT. The sections were washed and then stained with a labeled anti-eppin antibody while protected from light for an additional $60 \mathrm{~min}$ at RT. When the staining was complete, the sections were washed three times with PBS and then post-fixed in a $4 \%$ PFA solution in PBS for 15 min at RT. After the fixation, the sections were washed three times with PBS and counterstained with DAPI (Beyotime) for $15 \mathrm{~min}$, followed by a brief wash in PBS. Finally, the sections were analyzed under a Zeiss confocal laser microscope.

Western blotting. Protein was extracted from the GC-1, GC-2 and MCLT-1 cell lines using M-PER ${ }^{\circledR}$ Mammalian Protein Extraction Reagent (Pierce Bio, Thermo) according to the manufacturer's instructions. Briefly, the culture medium was carefully removed and the cells were washed once in $0.01 \mathrm{M}$ PBS. The M-PER Reagent was then added to the cells (200 $\mu \mathrm{l} /$ well of a 6-well plate) and shaken gently for $5 \mathrm{~min}$. The lysate was then collected and transferred to a $1.5-\mathrm{ml}$ microcentrifuge tube, sonicated, and centrifuged at 14,000 x g for $10 \mathrm{~min}$ at $4^{\circ} \mathrm{C}$. The supernatant was then transferred to a new 1.5-ml microcentrifuge tube on ice. Testes from 8-week-old mice were snap-frozen in $\mathrm{N} 2$ and homogenized in sample buffer [110 mM SDS, $100 \mathrm{mM}$ DTT, $80 \mathrm{mM}$ Tris (pH 6.9), $10 \%$ glycerol and $0.002 \%$ bromophenol blue] using a Dounce homogenizer. Each sample $(30 \mu \mathrm{g})$ was resolved on a $12 \%$ reducing gel. After transfer to a PVDF membrane, the blot was probed with either an anti-mouse eppin antibody (Santa Cruz) or anti-human eppin antibody (Santa Cruz).

\section{Results}

Distribution of mEppin mRNA in GC-1, GC-2 and MLTC-1 cell lines and adult mouse testis. In the GC-1 cell line, mEppin mRNA was localized to the cytoplasm, including the perinuclear region (Fig. 1g, arrows). The sense probe and PBS supplement only showed non-specific binding to cells (Fig. 1h and i). In the GC-2 cell line, the mEppin mRNA signal was relatively intense in the cytoplasm of the cell, and some positive signal was also observed in the nucleus (Fig. 1d, arrows). No signal was detected in the controls (Fig. 1e and f). At a higher magnification (Fig. 1a), the positive signal for mEppin mRNA was diffuse throughout the entire cytoplasm of the MLTC-1 cells (Fig. 1a, arrows) and the non-specific signal was detected in the controls (Fig. 1b and c). In situ hybridization of mouse adult testis showed a positive signal for mEppin mRNA in the perinuclear region of the spermatogonia (Fig. 2b, arrowhead). Moreover, relatively intense signals were observed throughout the entire spermatocytes, including the nuclear region (Fig. 2b, arrow). Furthermore, very few positive signals were observed in the elongated sperm in the seminiferous tubules (Fig. 2b, circle). Consistent with the results from the cell lines, mEppin mRNA expression was also detectable in Leydig cells, which were located in the regions between the seminiferous tubules (Fig. 2c, arrow). There were no specific positive signals in the controls (Fig. 2d and e).

PCR analysis and Western blotting. Reverse transcriptionpolymerase chain reaction (RT-PCR) analysis using primers specific to the coding sequence of mEppin showed consistent results with those obtained from the in situ hybridization. As shown in Fig. 3a, cDNAs from adult mouse testis as well as the GC-1, GC-2 and MLTC-1 cell lines respectively showed a 405-bp band that corresponded to the predicted size of mEppin (Fig. 3A, lanes 2, 3, 4 and 5). Mouse liver cDNA was used as a negative control and showed no bands (data not shown). Western blot analysis was then performed on lysates from each cell line and from adult mouse testis using an anti-mouse eppin antibody conjugated to horseradish peroxidase (HRP) produced in goats (Santa Cruz) or using the same antibody pre-incubated with mEppin peptide (Santa Cruz). As shown in Fig. 3B (lanes 1 and 2), a strongly reactive band of approximately $23 \mathrm{kDa}$ was observed in the GC-1 and GC-2 cell lines. Notably, a positive Western blotting signal was observed at 23 and $45 \mathrm{kDa}$ in the MLTC-1 cell line and in the mouse testis (Fig. 3B, lanes 3 and 4). No signal was observed when the primary antibody was absorbed with mEppin peptide (Fig. 3B, lane 5). In human testis, positive signals were observed at $\sim 35$ and $72 \mathrm{kDa}$ (Fig. 3B, lane 7).

Expression of mEppin in spermatogonia. To confirm that mEppin protein was expressed in the spermatogonia, an anti-c-kit antibody produced in rats was used to detect the spermatogonia, and the sections were co-incubated with an anti-eppin antibody produced in goats to detect mEppin protein. The results showed that the spermatogonia (Fig. 4a, gray color) were located around the luminal boarder. The mEppin protein (Fig. 4b, gray color) was diffused along the entire lumen of the seminiferous tubules in the testis. The merged image showed that the mEppin protein was expressed in the spermatogonia (Fig. 4c). In the control, no signals were detected on the lumen of the seminiferous tubules (Fig. 4d).

Distribution of eppin protein in human testis. Previous studies have indicated that hEppin protein is predominantly expressed in Sertoli cells and to a lesser extent in germ cells (8). However, there is little evidence of hEppin localization to spermatogonia in the adult human testis. Here, we observed green fluorescence staining of the spermatogonia (Fig. 5b and f), some of the spermatogonia (Fig. 5f, short arrows) located around the seminiferous tubule, and some earliest preleptotene spermatocytes dispersed throughout the lumen (Fig. 5f, long arrow). The red fluorescence of hEppin protein was diffuse throughout the entire seminiferous tubule (Fig. 5c and g), and the merged images showed that the expression of hEppin protein was localized to differentiated spermatogonia and the earliest preleptotene spermatocytes in the human testis (Fig. 5d and h). The nuclei were delineated by DAPI (blue).

\section{Discussion}

The data obtained in this study by in situ hybridization, PCR analysis and Western blotting clearly demonstrate the 


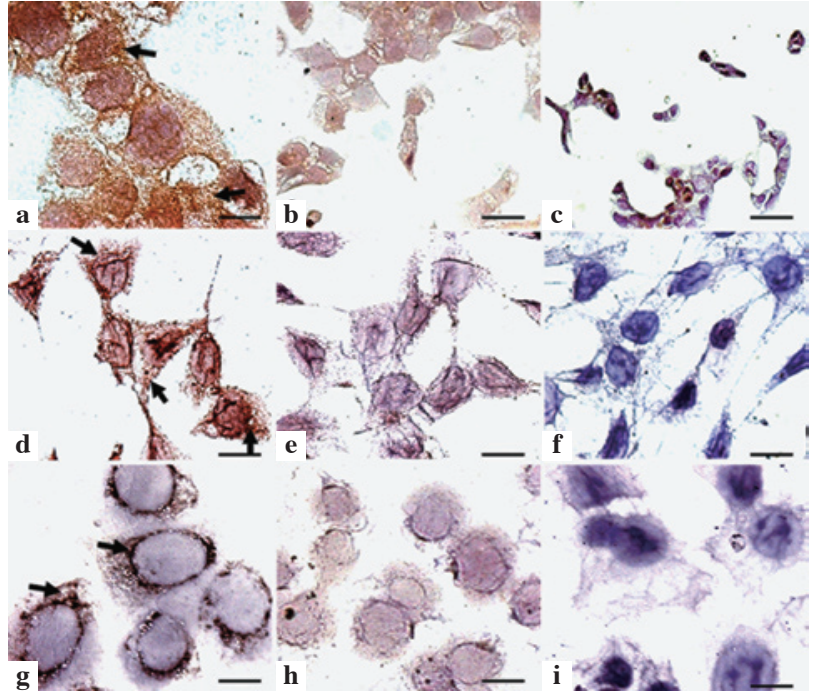

Figure 1. In situ hybridization of MLTC-1, GC-2 and GC-1 cell lines using antisense (a, $\mathrm{d}$ and $\mathrm{g}$ ) and sense ( $\mathrm{b}$, e and $\mathrm{h}$ ) probes to mEppin, and a PBS control (c, f and i). Bars: a, d, e,f, g and i, $500 \mu \mathrm{m} ; \mathrm{h}, 400 \mu \mathrm{m} ; \mathrm{b}, 200 \mu \mathrm{m} ; \mathrm{c}, 50 \mu \mathrm{m}$.

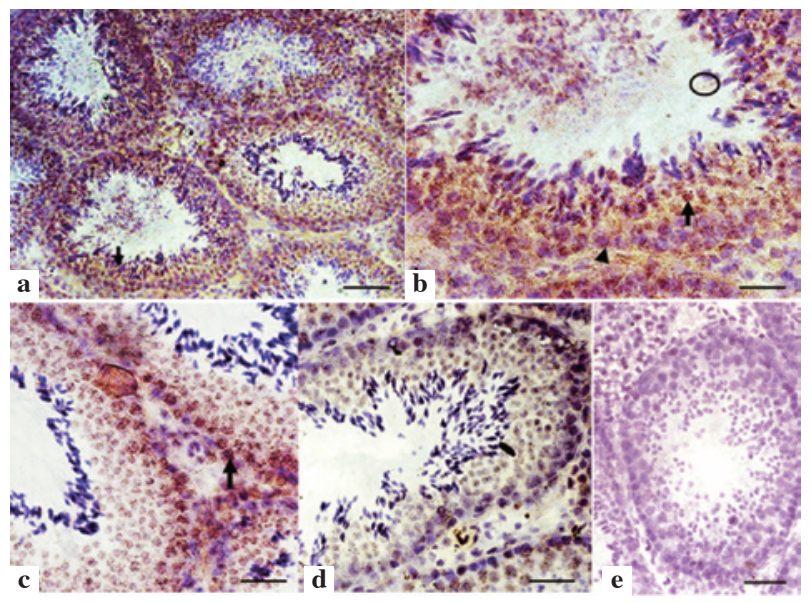

Figure 2. In situ hybridization of the testis from a 60-day-old mouse using antisense (a, b and c) and sense (d) probes to mEppin, and a PBS control (e). (a) Localization of mEppin mRNA in the testis from a 60-day-old mouse. (b) Magnification of (a); spermatogonia (triangular arrow), spermatocytes (swallowtail arrow), elongated spermatide (ellipse). (c) The region between seminiferous tubules; Leydig cells (lacetti arrow). Bars: a, $50 \mu \mathrm{m} ; \mathrm{b}, \mathrm{c}, \mathrm{d}$ and e, $100 \mu \mathrm{m}$.
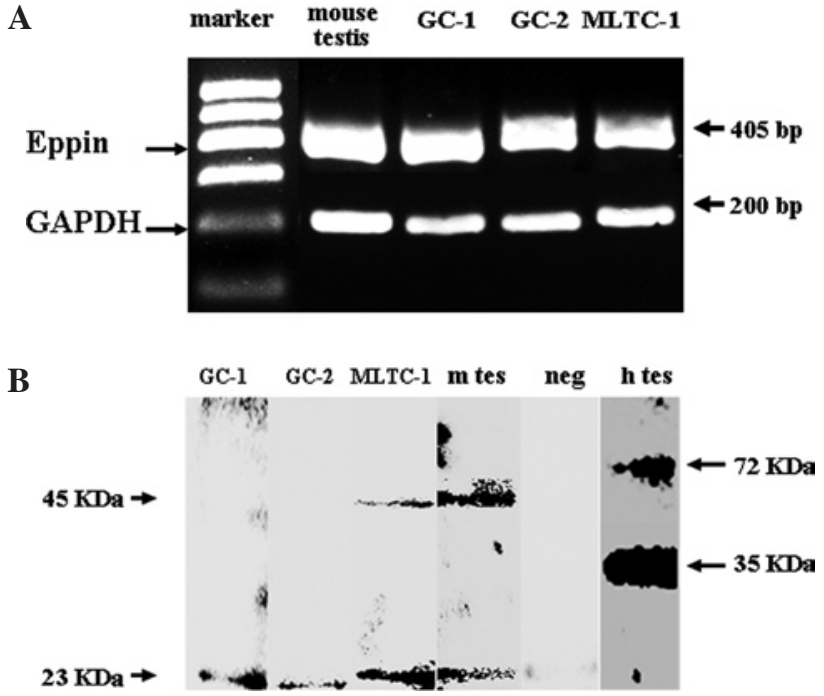

Figure 3. PCR and Western blot analysis. (A) PCR analysis of mEppin expression in germ cell lines and mouse testis extracts using specific primers. The positions of the specific bands are marked on the right. (B) Western blot analysis of mEppin expression in germ cells lines and mouse testis, as well as of hEppin in human testis respectively probed with anti-eppin antibody. $\mathrm{m}$ tes, 60-day-old mouse testis; neg, primary antibody pre-absorbed with eppin peptide; $h$ tes, human testis.

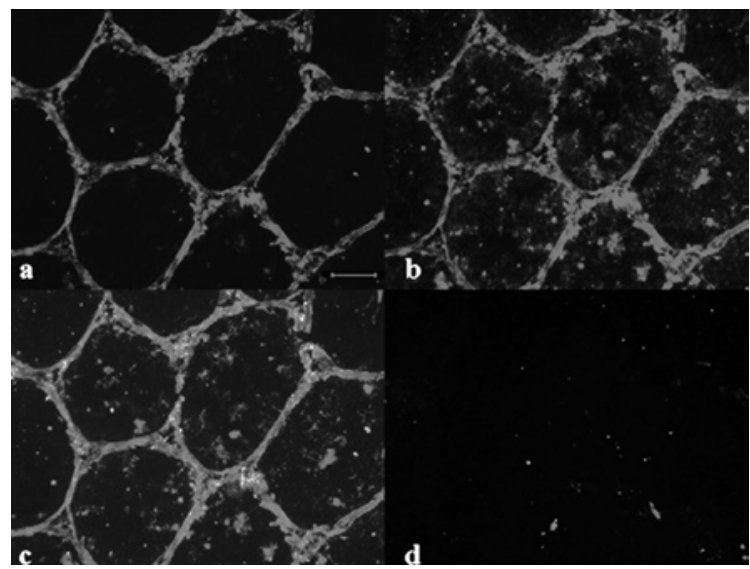

Figure 4. Localization of mEppin protein in spermatogonia. (a-c) Double immunofluorescence on the testis from a 60-day-old old mouse with an antic-kit antibody and anti-mouse eppin antibody. (d) Control. Bar, $50 \mu \mathrm{m}$.

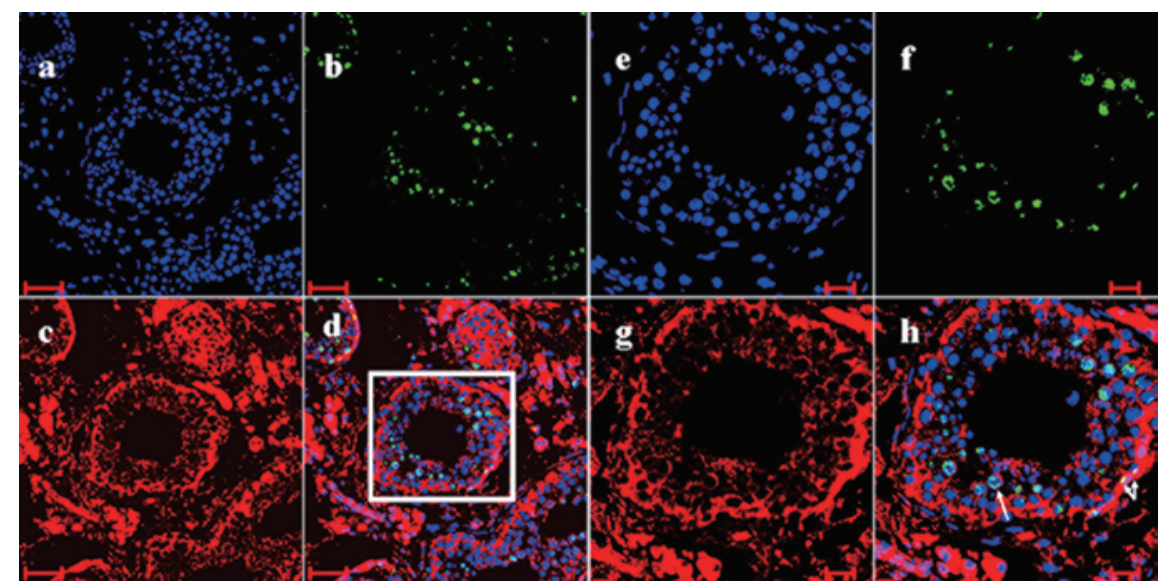

Figure 5. Localization of hEppin in human testis. (e-h) Magnification of (a-d). Double immunofluorescence on human testis with anti-c-kit antibody and antihuman eppin antibody. Green, c-kit-positive cells; red, hEppin; blue, nuclei. Scale bars, $50 \mu \mathrm{m}$. 
distribution pattern of mEppin mRNA in different germ cell lines and mouse testis. Furthermore, fluorescent immunohistochemistry showed that both mEppin protein and hEppin were expressed in differentiated spermatogonia. Moreover, these results provide direct evidence that mEppin protein was secreted from Sertoli cells and taken up by spermatogonia. Sivashanmugam et al had previously shown by immunohistochemistry mEppin protein localized to Leydig cells, Sertoli cells and the acrosome of round spermatids in mouse testis (9). However, there has not been a detailed description regarding the distribution pattern of mEppin mRNA in viripotent mouse testis. Wang et al indicated in an earlier study that hEppin protein was primarily localized to Sertoli cells and showed limited expression in myoid and spermatogenic cells in human testis (8). However, these results had not been confirmed.

In the present study, the results of in situ hybridization showed that mEppin mRNA was expressed in spermatogonia (GC-1), spermatocyte (GC-2) and Leydig (MLTC-1) cells. Moreover, we found that mEppin mRNA is localized to spermatogonia, spermatocytes and Leydig cells in adult mouse testis. The PCR analysis was consistent with the results obtained by in situ hybridization. It is well established that gene function is guided by protein type; we therefore assessed mEppin localization to A1-A4 spermatogonia using an antic-kit antibody to stain A1-A4 spermatogonia and an anti-eppin antibody to stain mEppin protein. Our results showed that mEppin protein was expressed in A1-A4 spermatogonia.

Previous studies in mice have described seven types of A spermatogonia, including Asingle, Apair, Aaligned, A1, A2, A3 and A4. The Asingle spermatogonia are considered to be the spermatogonia stem cells, the Apair and Aaligned spermatogonia are clonally further expanded colonies that are not synchronized with the seminiferous epithelial cycle, and the A1-A4 spermatogonia are considered further expansions of these spermatogonial clones synchronized with the seminiferous epithelial cycle (13). In the testes of newborn mice, the seminiferous cords contain only non-proliferating goocytes (T1 prospermatogonia) and Sertoli cells. Type A spermatogonia first appear in the tubule on day 6 after birth, at which time the significant expression of c-kit can be detected (14). A previous study showed that mEppin protein is absent in 7-day-old mice and present in Sertoli cells in 12-day-old mice (9). This directly demonstrates that mEppin protein is secreted from Sertoli cells and taken up by A1-A4 spermatogonia during the process of spermatogenesis. It is generally accepted that Sertoli cells are crucial for the successful progression of spermatogonia into spermatozoa. Proteins secreted by Sertoli cells that play a role in spermatogenesis can be divided into three categories. Among these categories are the proteases and proteases inhibitors, which play an key role in the tissue remodeling process during spermiation and in the movement of preletotene spermatocytes into the adluminal compartment of the seminiferous tubule (15). The mEppin protein is a member of a highly conserved family of protease inhibitors that are expressed in the testis and epididymis, and mEppin expression is linked to protease expression (9). The role mEppin plays in spermatogenesis when secreted from Sertoli cells remains unclear and requires further study. Notably, the expression of hEppin protein was also localized to the spermatogonia. A previous study showed that c-kit is detected on the surface of the intermediate, type B spermatogonia and the earliest preleptotene spermatocytes in addition to A1-A4 spermatogonia, whereas no c-kit expression was detected in later spermatocytes or Sertoli cells (14).

The findings of the present study are partially consistent with these previous studies, as they show that hEppin protein is expressed in the spermatogonia and the earliest preleptotene spermatocytes. The localization of mouse and human eppin in the testis was similar. We therefore suggest that the mouse is potentially a suitable animal model for studies of hEppin.

\section{Acknowledgements}

We thank Dr Michael G. O'Rand (Laboratories for Reproductive Biology and Department of Cell and Developmental Biology, University of North Carolina at Chapel Hill) for the scientific instructions. This study was supported by grants from the National Eleventh-Five Science and Technology Support Program of China (no. 2006BAI03B12) the National Basic Research Program of China (973 Program) (no. 2009CB941703) and the Natural Science Foundation of Jiangsu Province (no. BK2010431).

\section{References}

1. Bedford JM: Effects of duct ligation on the fertilizing ability of spermatozoa from different regions of the rabbit epididymis. J Exp Zool 166: 271-282, 1967.

2. Orgebin-Crist MC: Sperm maturation in rabbit epididymis. Nature 216: 816-818, 1967.

3. Fritz IB, Tung PS and Ailenberg M: Proteases and anti-proteases in the seminiferous tubule. In: The Sertoli Cell. Russell LD and Griswold MD (eds). Cache River Press, Clearwater, FL, USA, pp217-235, 1993.

4. Okanlawon A and Dym M: Effect of chloroquine on the formation of tight junctions in cultured immature rat Sertoli cells. J Androl 17: 249-255, 1996.

5. Richardson RT, Sivashanmugam P, Hall SH, et al: Cloning and sequencing of human Eppin: a novel family of protease inhibitors expressed in the epididymis and testis. Gene 270: 93-102, 2001.

6. Denolet E, De Gendt K, Allemeersch J, et al: The effect of a sertoli cell-selective knockout of the androgen receptor on testicular gene expression in prepubertal mice. Mol Endocrinol 20: 321-334, 2006.

7. O'Rand MG, Widgren EE, Sivashanmugam P, et al: Reversible immunocontraception in male monkeys immunized with eppin. Science 306: 1117, 2004.

8. Wang Z, Widgren EE, Richardson RT and O'Rand MG: Characterization of an eppin protein complex from human semen and spermatozoa. Biol Reprod 77: 476-484, 2007.

9. Sivashanmugam P, Hall SH, Hamil KG, French FS, O'Rand MG and Richardson RT: Characterization of mouse Eppin and a gene cluster of similar protease inhibitors on mouse chromosome 2. Gene 312: 125-134, 2003.

10. Russell LD: Role in spermiation: In: The Sertoli Cell. Russell LD and Griswold MD (eds). Cache River Press, Clearwater, FL, USA, pp269-303, 1993.

11. Cheng CY and Mruk D: Cell junction dynamics in the testis: sertoli-germ cell interactions and male contraceptive development. Physiol Rev 82: 825-874, 2002.

12. Oda K, Makino S, Masuda C, et al: The mRNA distribution of C7orf24, a g-Glutamyl cyclotransferase in rat tissues. J Histochem Cytochem 57: 1121-1126, 2009.

13. Ehmcke J, Wistuba J and Schlatt S: Spermatogonial stem cells: questions, models and perspectives. Hum Reprod Update 12: 275-282, 2006

14. Yoshinaga K, Nishikawa S, Ogawa M, Hayashi S, Kunisada T, Fujimoto T and Nishikawa S: Role of c-kit in mouse spermatogenesis: identification of spermatogonia as a specific site of c-kit expression and function. Development 113: 689-699, 1991.

15. Sofikitis N, Pappas E, Kawatani A, et al: Efforts to create an artificial testis: culture systems of male germ cells under biochemical conditions resembling the seminiferous tubular biochemical environment. Hum Reprod Update 11: 229-259, 2005. 